\title{
EFFECIENCY AND PERSISTENCE OF DIAZINON INSECTICIDE ON DIFFERENT SURFACES AGAINST SITOPHILLUS ORYZAE (L.) AND RHIZOPERTHA DOMINICA (F.)
}

\author{
MAHGOUB, SANAA M., M.E.H. NASR, SALWA M.S.AHMED \\ and MAWAHIB M. ZEWAR ${ }^{1}$
}

Plant Protection Research Institute, ARC, Dokki, Giza, Egypt.

(Manuscript received 29 November 2012)

\begin{abstract}
A laboratory studies were undertaken to assess the efficacy of Diazinon insecticide (EC). Formulation of insecticide were applied to different surfaces i.e. steel, ceramic, wood and cement at 0.0006 and $0.0003 \mathrm{ml} / \mathrm{cm}^{2}$ to determine their persistence up to 28 weeks against Sitophilus oryzae (L.) and Rhizopertha dominica (F.). Insects were exposed on the treated surfaces for 24 hrs. at 28 weeks after treatment. Results indicated that; mortality rates were positively corrected with the concentration and negatively corrected with the time of application. The results indicated that:

$>$ Steel and ceramic were the most persistent surfaces which gave $100 \%$ mortality up to 18 and 20 weeks at the highest concentration in both tested insects respectively.

> Wood surface can provide good protection only up to the tenth and eighth weeks after application at the highest concentration for $S$. oryzae and $R$. domonica respectively.

$>$ In cement surface, Diazinon deteriorated very rapidly starting from the first two weeks at $0.0006 \mathrm{ml} / \mathrm{cm}^{2}$ on both tested insects.

> Values of gross persistency of the different surfaces indicated that steel and ceramic surfaces were the most ideal to retain toxicity followed by wood surface, meanwhile cement surface lost most of its efficiency when used.

> Finally, Rizopertha dominica (F.) adults were more tolerant to insecticide than $S$. oryzae (L.).
\end{abstract}

\section{INTRODUCTION}

It is common practice in many developing countries to spray the grain stores with residual formulations of contact insecticides to control stored-product insects, this is achieved by first killing the insect present, and secondly by leaving a persistent deposit, which continues to kill insects arriving on the surface.

The surfaces commonly sprayed include walls, floor and bag-stacks. Materials which are likely to be sprayed therefore are concrete, wood, metal and sacking such as jute, sisal, polypropylene and multi-wall paper.

A residual insecticide is first deposited as an overdose which continues to kill the target pests until the concentration of available residue has dropped to a sub- 
lethal level. Depletion of this available residue takes place by a number of means, including oxidation, volatilization, sorption into the substrate, and removal by insect pick-up, or other disturbance such as weathering, accidental abrasion or cleaning. (Hodges and Dales 1991), (Hodges 1993), (Hodges et. al., 1989) and (Nayak et. al., 2002).

The aim of the study is to evaluate the efficiency and persistence of Diazinon insecticide against Sitophilus oryzae (L.) and Rhizopertha dominica (F.) after their application on different surfaces such as steel, ceramic, wood and cement by two tested concentration i.e. 0.0006 and $0.0003 \mathrm{ml} / \mathrm{cm}^{2}$.

\section{MATERIALS AND METHODS}

Two species of stored grain insects were used in the study, rice weevil, Sitophilus oryzae and the lesser grain borer, Rhizopertha dominica cultures of both species were maintained at $27 \pm 1^{\circ \mathrm{C}}$ and $65 \pm 5 \% \mathrm{RH}$.

Commercial formulation of Diazinon $60 \%$ (E.C) insecticide was used for surface treatment. Tested two concentrations were 0.0006 and $0.0003 \mathrm{ml} / \mathrm{cm}^{2}$.

Diazinon insecticide was sprayed over different surfaces i.e. (steel, ceramic, wood and cement). Every surface prepared as a circular discs (9cm diameter) in individual Petri dishes $(1.5 \mathrm{~cm}$ high $\times 9 \mathrm{~cm}$ diameter), while, cement discs were prepared by mixing $3200 \mathrm{~g}$ of cement in $1600 \mathrm{ml}$ of water to a thick running consistency, which was subsequently poured into individual Petri dishes.

Fifty insects of each $S$. oryzae or $R$. dominica were released on each Petri dish. Mortalities were counted after 24 hrs. (Initial treatment).

To evaluate the persistence efficiency of the used surfaces against the tested insects, 50 insects were introduced periodically to each Petri-dish at one week and up to 28 weeks after initial treatments. In all cases, three replicates were made for each treatment and the untreated check.

Percent mortalities were calculated and corrected with Abbott`s formula (1925). Gross persistency values were worked out according to the formula used by Power and Yadav (1980) as follows:

Gross persistency $=\underline{\text { sum of }(\% \text { mortality } \times \text { period days })}$

Number of observations 


\section{RESULTS AND DISCUSSION}

Data in tables (1) \& (2) showed clearly that the mortality rates were positively corrected with the time of application. At two tested concentrations, steel and ceramic surfaces were more persistence than wood and cement surfaces. Steel and surface gave $100 \%$ mortality to $S$. oryzae up to 20 and 18 weeks at 0.0006 and $0.0003 \mathrm{ml} /$ $\mathrm{cm}^{2}$. The corresponding data were 18 and 16 weeks at the two previous concentrations for $R$. dominica, respectively.

The reduction in the efficiency of Diazinon insecticide was relatively moderated in wood surface at two tested concentrations. Wood surface can provide good protection up to the tenth and eighth weeks after application at the highest concentration for $S$. oryzae and $R$. domonica respectively.

In cement surface, Diazinon deteriorated very rapidly starting from the first two weeks on $0.0006 \mathrm{ml} / \mathrm{cm}^{2}$ and from the first week at $0.0003 \mathrm{ml} / \mathrm{cm}^{2}$ in both tested insects. These results agree with the Power Yadav (1980) who sprayed some surfaces by some insecticides against adults of C. chinensis.

The values of gross persistency of the different surfaces were tabulated in Tables $1 \& 2$ and indicated that steel and ceramic surfaces were the most ideal to retain toxicity followed by wood surface; meanwhile cement surface lost its efficiency rapidly. These results indicated that Diazinon insecticide was more persistent on non porous surfaces. Similar results had already been shown against $C$. chinensis using glass, metallic and plywood surface (Cogburn 1972), also (Mahgoub 1995) had pointed out that the porosity of surface was responsible for less persistency.

It can be concluded that fair protection of tested stored grain insects up to 20 weeks could be achieved through surface treatment of steel and ceramic with 0.0006 $\mathrm{ml} / \mathrm{cm}^{2}$. 

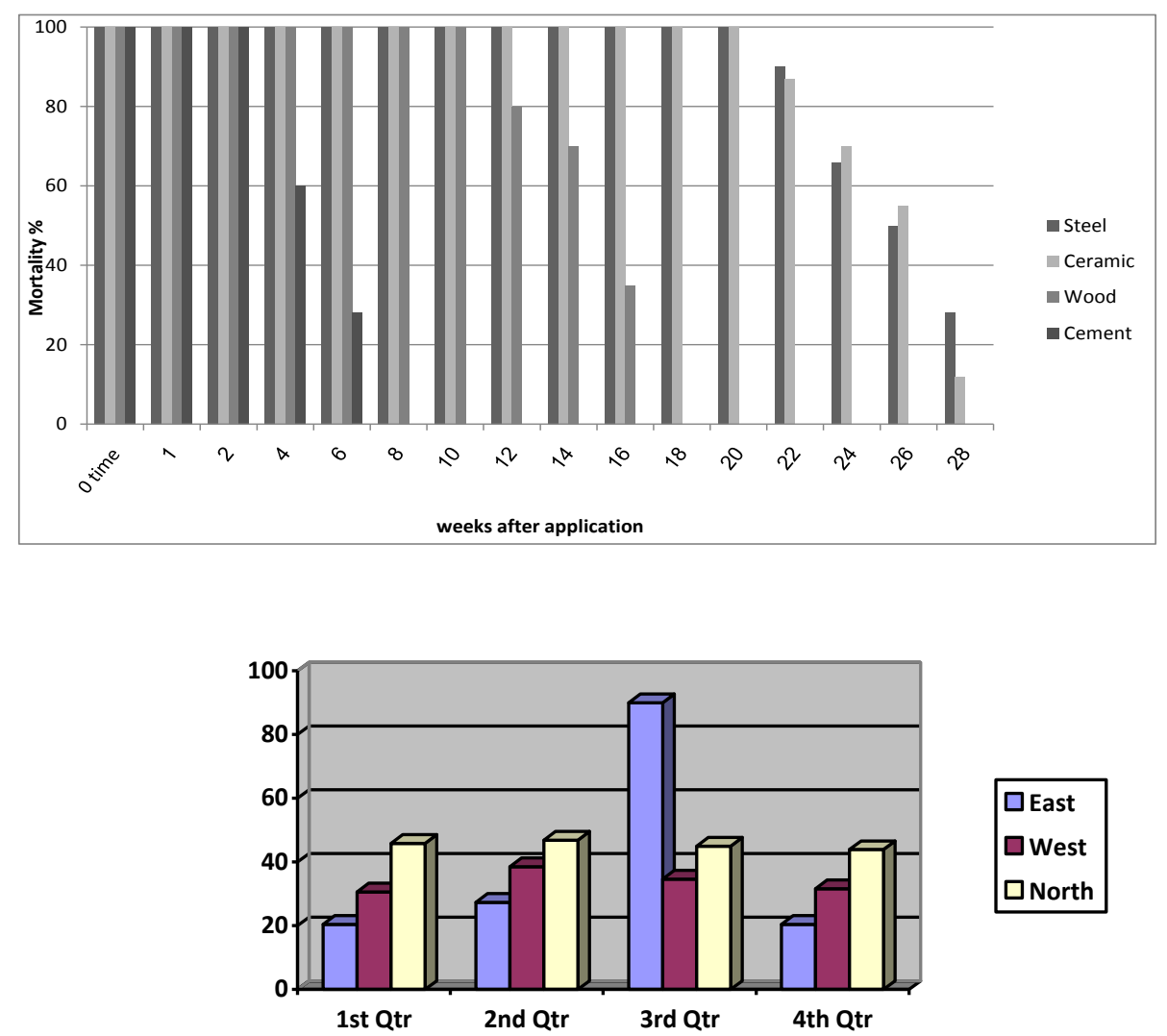

Fig. 1. Persistence of Diazinon $60 \%$ insecticide on different surfaces against S. oryzae indicated by percent mortality Conc. $\left(0.0006 \mathrm{ml} / \mathrm{cm}^{2}\right)$.

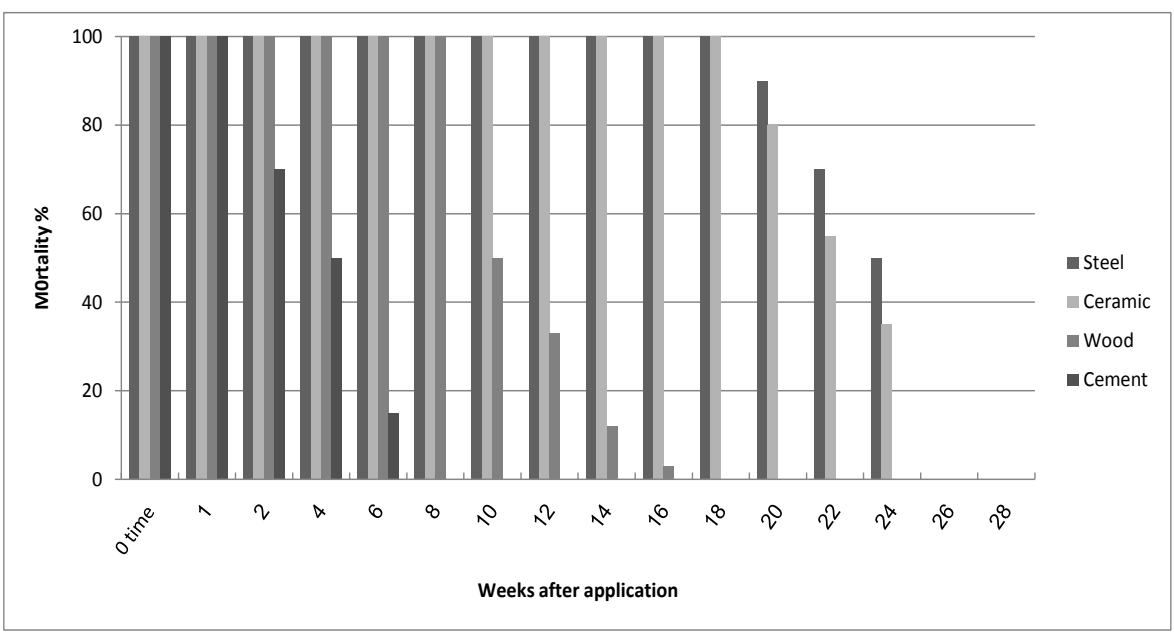

Fig. 2. Persistence of Diazinon $60 \%$ insecticide on different surfaces against S. oryzae indicated by percent mortality Conc. $(0.0003 \mathrm{ml} / \mathrm{cm} 2)$. 


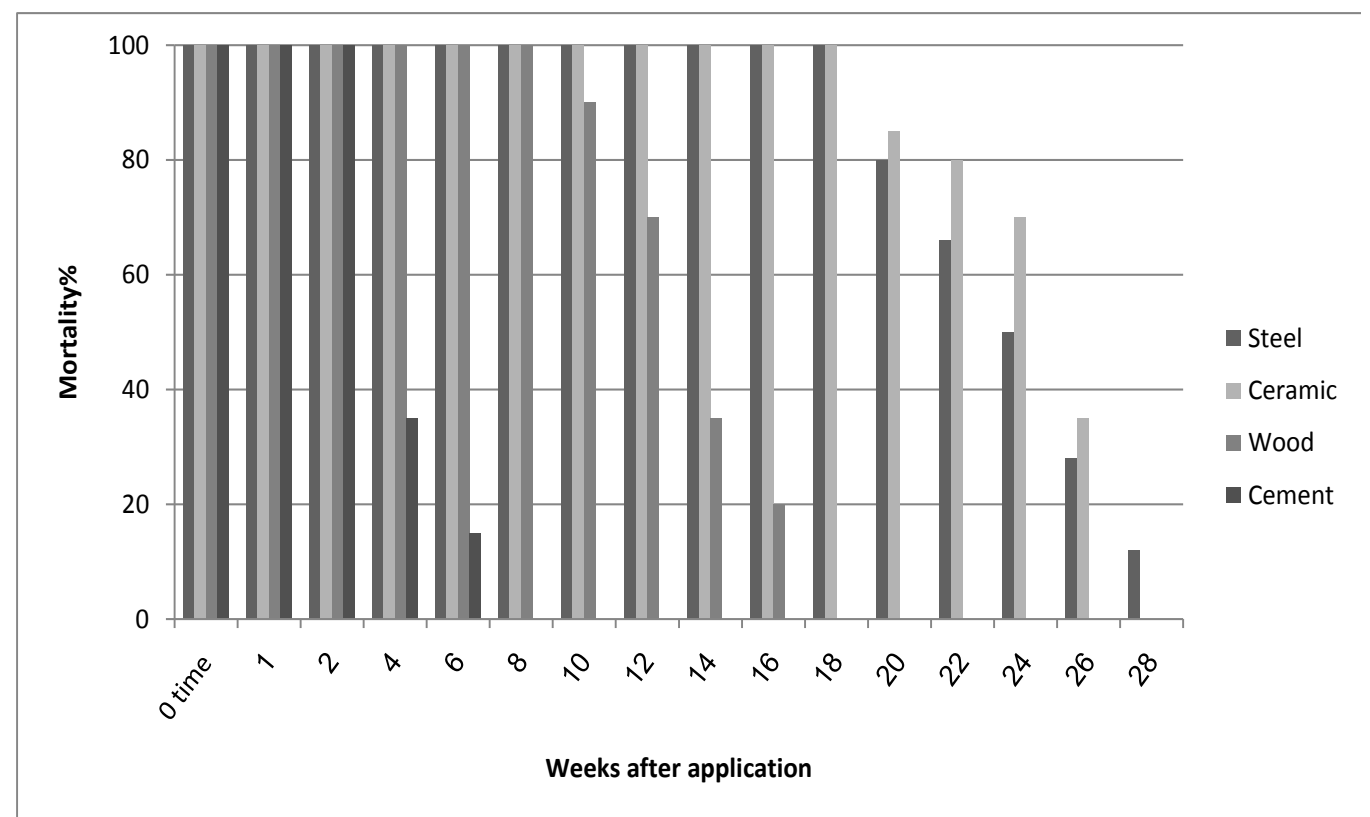

Fig. 3. Persistence of Diazinon insecticide on different surfaces against R. dominica F. indicated by percent mortality Conc. $(0.0006 \mathrm{ml} / \mathrm{cm} 2)$

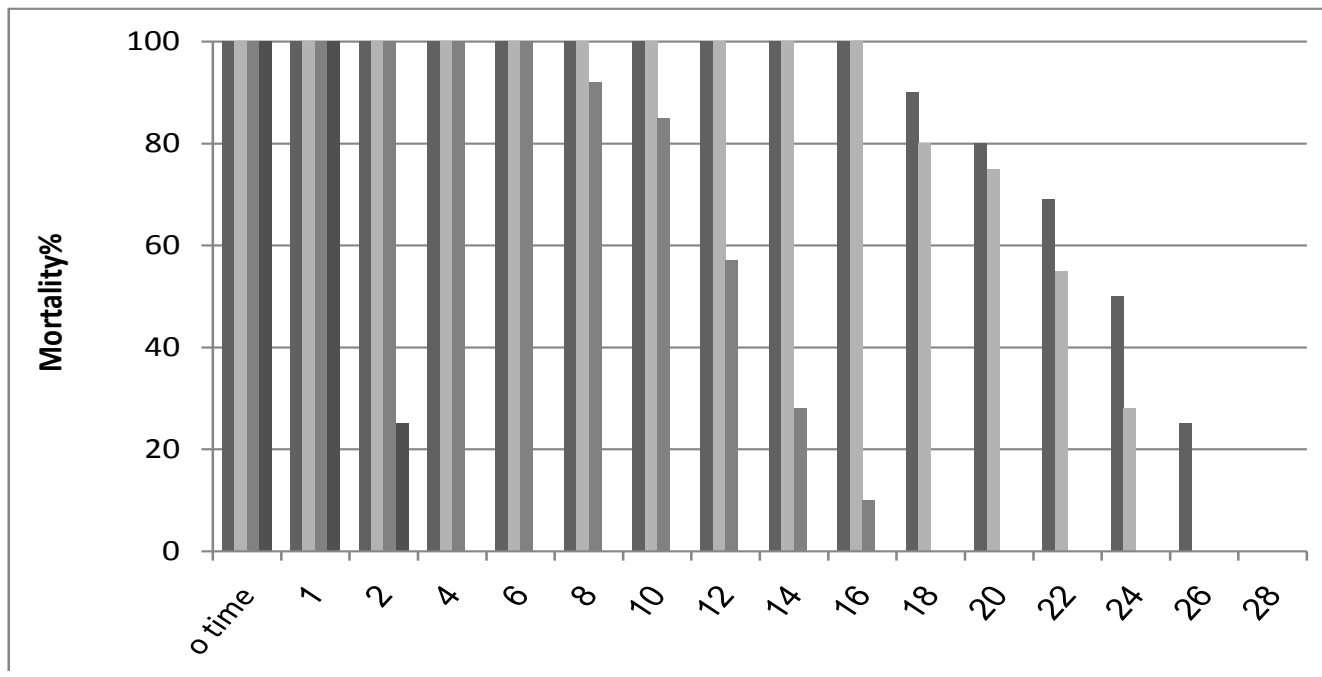

Fig. 4. Persistence of Diazinon insecticide on different surfaces against R. dominica F. indicated by percent mortality Conc. $(0.0003 \mathrm{ml} / \mathrm{cm} 2)$. 


\section{REFERENCES}

1. Abbott, W. S. 1925. A method of computing the effectiveness of an insecticide. J. Econ. Ent. 18, 265-267.

2. Cogburn, R. R. 1972. Natural surfaces in Gulf port were house influence on toxicity of Malathion and Gardona to confused flour beetle. J.econ. Ent. 65 (6). $1706-1709$.

3. Hodges, R. J. 1993. The relative efficacy of control insecticide sprayed onto store, wall surface in Mali West Africa. NRI Report R 2027, 9 P. 'rt56

4. Hodges, R. J. Nataredja, C. Yun and P. Suharno. 1989. Cost reductions in the treatment of milled-rice store structures with contact insecticides. In: Naewbanji. J. O. ed., proceedings of the twelfth ASEAN seminar or grain postharvest technology. Surabaya, Indronesia, 29-31 August 1989, 75-86.

5. Hodges, R. J. and M. J. Dales. 1991. Report on an investigation of insecticide persistence on grain store surface in Ghana, 3 April- 10 May 1991.

6. Mahgoub. M. S. 1995. Persistence of certain petroleum fractions on different surfaces against the cowpea beetle, C. maculatus Egyp. J. Agric. Res. 73 (4).

7. Nayak M. K., P. J. Collins and H. Paric. 2002. Long-term effectiveness of grain protectants and structural treatments against Liposcelis decolor, a pest of stored products. Pest Manag. Sci. 58: 1223- 1228.

8. Power, C. S. and T. D. Yadav. 1980. Persistence of organophosphorus insecticides on different surfaces. Indian J. Ent. 42 (4): 728- 736. 
تأثير ويقاء مبيد الايازينون على أسطح المواد المختلفة ضد حشرتى سوسة الأرز

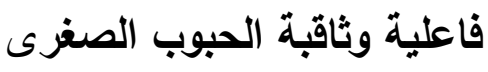

سناء محمود محجوب ، محرو السبد حسن نصر ، سلوى مصطفى سيد أحمد ، مواهب محمود زيوار

$$
\text { معهُ بحوث وقاية النباتات - مركز البحوث الزراعية - اللقي - جيزة - مصر }
$$

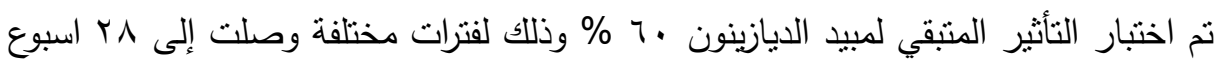
على بعض الأسطح المختلفة مثل الصفيح ، السيراميك ، الخشب والأسمنت ضد حشرتى سوسة الأرزو ثاقبة الحبوب الصغرى وقد أثبتت الدراسة الآتي:-

- اختلف نأثير المبيد المستخدم على حشرات الاختبار تبعا لإختلاف تركيز المبيد المستخدم ولاختلاف نوع السطح المعامل. - أعطى سطحي الصفيح والسيراميك أعلى بقاء وتأثيرا على حشرات الاختبار حيث أعطيا نسبة موت .

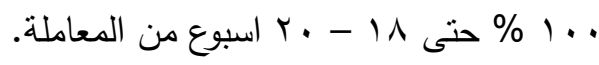

- أعطى سطح الخشب المعامل نأثير بقائي أقل حيث أعطى نسبة موت . . 1 \% حتى الاسبوع العاثر فقط لحشرة سوسة الأرز والأسبوع الثامن لحشرة ثاقبة الحبوب الصغرى.

- أعطى سطح الأسمنت أقل كفاءة بقائية حيث حدث تدهورا واضحا وصل إلى اسبوعين فقط بعد المعاملة في الحشرات المختبرة.

- كانت حشرة ثاقبة الحبوب الصغرى أكثر تحملا للمبيد عند مقارنتها بحشرة سوسة الأرز . 